\title{
TRIP11 wt Allele
}

National Cancer Institute

\section{Source}

National Cancer Institute. TRIP11 wt Allele. NCI Thesaurus. Code C97862.

Human TRIP11 wild-type allele is located within 14q31-q32 and is approximately $73 \mathrm{~kb}$ in length. This allele, which encodes thyroid receptor-interacting protein 11, is involved in binding to the Golgi membrane, microtubules and the thyroid receptor. Mutation of the gene is associated with achondrogenesis type $1 \mathrm{~A}$ and a chromosomal translocation $t(5 ; 14)(q 33 ; q 32)$ of this gene and the PDGFRB gene is associated with acute myelogenous leukemia. 